\title{
Deanne Williams. Shakespeare and the Performance of Girlhood. New York: Palgrave Macmillan, 2014. Pp xi, 277.
}

M. TYLER SASSER

University of Alabama
Early Theatre 19.1 (2016), 164-7

http://dx.doi.org/10.12745/et.19.1.2910

Shakespeare and the Performance of Girlhood is a strikingly rich addition to the growing body of scholarship on Shakespeare and early modern childhood. Deanne Williams fully demonstrates 'how Shakespeare created girl characters and defined the idea of girlhood over the course of his career, shaping and inspiring subsequent literary and cultural representations of girls and conceptions of girlhood' throughout late seventeenth-century English culture (2).

As Williams explains, 'Shakespeare typically uses the term "girl" when a character's relationship to authority is complicated or troubled' (4). In Shakespeare's early plays, 'girl' is 'a label for a young woman's independence, willfulness, and resistance', but by the end of his career, 'girl' becomes a character 'who exhibit[s] bravery and integrity in the face of misfortune', as well as an insult for males (6). Thus, for Williams's purposes, girl 'is not limited to chronology or biology' (6). Rather, "the variety of meanings attached to "girl" in the early modern period offer $[$ sic] a range of possibilities and contexts ... that were not so much contradictory ... as creatively and imaginatively enabling' (5-6). Such a capacious definition allows Williams to study an entire range of girls, including Joan La Pucelle, Ophelia, Queen Isabella, and even Romeo and Macbeth, as well as historical girls inspired by Shakespeare's works.

Williams's purposes are threefold: to examine 'girl characters (usually performed by boy actors), historical girls (both as they are represented by Shakespeare and how they represent themselves), and the idea of the "girl" itself as a rhetorical construct' (6). She accordingly divides her study into three sections: 'Shakespeare's Girls', 'Stages of Girlhood', and 'Writing Girls'. Williams begins by focusing on those girls who are 'peevish and perverse', which is to say girls who not only 'perform their status as girls, but also, through resistance and mutability, ... become themselves' (25). She first considers the contradictory representation of Joan La Pucelle (Joan of Arc) in 1 Henry VI. In wearing a soldier's armour, La Pucelle recalls the origins of 'girl' as a term for both female and male children (23). 'La Pucelle's identification as a "girl" through her acts of resistance', explains Williams, 'highlights the enabling variety of possibilities and associations attendant upon girlhood in the early modern period' (24). Silvia and Julia in The Two Gentleman of Verona are characterized as 'peevish' and 'perverse' by disobeying 
their father, as is Bianca in The Taming of the Shrew, whose independence frustrates 'an expectation of daughterly submission' (36-7). Williams concludes the chapter by turning to Romeo and Juliet, suggesting Shakespeare introduces a 'new' kind of girl: while Juliet is a 'character whose mutability and movement, flexibility, resistance, and transformative creative imagination, dramatize the limitless possibilities of girlhood itself', Paris and Romeo too emphasize such possibilities when they are 'transformed into "girls" through their relationship with Juliet' (50). It is these characters' love that is peevish and perverse, since as Williams avers, 'Romeo's experience of love for Rosaline serves as a set of variations on a theme of perversity, ... the Nurse compares him to Juliet', and '[i]magining Romeo apotheosized after her death, Juliet turns him into a figure associated with the feminine night, as opposed to the traditionally masculine sunlight' (50).

Chapter 2 is an historical and biographical study of the child-bride as depicted by Queen Isabelle de France in Richard II. After reminding readers that the historical Queen Isabelle married Richard II in 1396, when she was seven and he twenty-nine, Williams invites us to imagine 'Shakespeare's version of this character through her historical counterpart, no longer glossing over the reality of her age, and instead consider how Shakespeare's dramatization of medieval child marriage both challenges our expectations about girlhood and broadens our understanding of medieval and early modern girls as dramatic characters, as well as historical individuals' (53). After a clear and fascinating discussion of medieval child-brides in England, Williams provides a close reading of the queen as a girl. In the end, her convincing analysis reveals something refreshingly new about the play, that to 'deny the historical Isabelle the dignity of her own experience [is to] overlook a key element in Shakespeare's Richard II' (71).

Chapter 3 centres on a stage direction from the first quarto of Hamlet (1603): 'Enter Ofelia playing on a Lute, and her hair down, singing' (73). For Williams, the lute, hair style, and singing evidences an Ofelia who is a 'more accomplished, more forthright and expressive' girl than the Ophelia of Q2 and F. Though her lengthy catalogue of lute representations in early modern culture convinces me of the frequency with which the instrument is associated with girlhood, I am less convinced this single Q1 stage direction communicates as much about girlhood as we have thus far come to expect from Williams's contextualization. Certainly artists throughout the Renaissance depicted women and girls playing the lute, but there also are numerous portrayals of men and boys playing the lute, including the boy performing Ofelia. I am not sure this stage direction can support some of Williams's larger claims in the chapter: 'A simple prop, Ofelia's lute props up the psyche of this vulnerable girl character. It transforms our understanding of this 
character beyond the familiar paradigms of hysteria and passivity, and allows us to associate her instead with the mastery of musical technique and the sangfroid of performance. Her lute suggests a character that is truly informed about the ways of the world, but is not as compromised by them' (91). However, Williams's use of Q1 to explore further her topic is typical of the book's strengths. Her close reading of Ofelia reminds scholars how important it is to take seriously the so-called 'bad' editions of Shakespeare.

In chapters 5 and 6 , Williams turns to the second part of her project, a focus on the 'complex, multi-authored genre of the Jacobean and Caroline masque, in which girls occasionally performed' (7). Having previously mapped out girls in Shakespeare, she now attempts to explain how historical girls found models of girlhood in Shakespeare. At the start of his career, Shakespeare depicted a girl's rebellion as peevish and perverse, yet by the end of his career 'this independence [was] key to their identities' (124). Such independence surfaces, for instance, in Queen Anne's involvement in court masque and Princess Elizabeth Stuart's participation in Tethy's Festival (1610). For reasons not fully explained, Williams shifts her focus away from Shakespeare at this point to dramas performed by the princess's own company, the Lady Elizabeth's Men; plays such as The Maid's Tragedy and A Chaste Maid in Cheapside 'dramatize a girl's wronged experience' (137), fairly akin to Elizabeth's own girlhood. She argues, however, that such texts 'speak to Elizabeth's theatrical experiences, and engage with the evolving dramatic representations of girlhood that we have seen in Shakespeare's work' (136). In chapter 6, Williams demonstrates how John Milton's A Mask Presented at Ludlow Castle is also invested in girlhood, especially regarding its dramatization of virginity. As Williams explains, " $[\mathrm{t}$ ]hrough the discourse of chastity, the debate between the Lady and Comus explores what it means for a girl to appear on state, ultimately constituting a defense of the girl performer against popular antitheatrical commonplaces about the immorality and lewdness of the stage' (149).

In the final section, Williams turns to historical girls who authored their own versions of girlhood based on Shakespeare. Chapter 7 considers Lady Rachel Fane (1613-80) who, writing as a girl, turned to the court masque and closet drama as a way to celebrate her theatrical family and personal interests in the theatre. Her May Masque (1627) finds inspiration in the dramatization of family in $A$ Midsummer Night's Dream, though Fane's specific depiction of dramatic girlhood reveals Fane's own fashioning of childhood. Chapter 8 considers texts written by Lady Elizabeth Brackley (1626-63) and Lady Jane Cavendish (1621-69) as girls in exile during the civil war. Their play Concealed Fancies, written while the Cavendish sisters were in captivity, depicts civil war politics from the perspective of its 
girl coauthors. Dramas such as As You Like It and The Taming of the Shrew influence Concealed Fancies as these sisters reclaim their domestic space and expectations within a wartime context.

Some readers may find the division between the first and final four chapters in Shakespeare and the Performance of Girlhood too significant for a single monograph, though most, as myself, will be generally pleased by the connections Williams makes to non-Shakespearean girls who exhibit Shakespearean characteristics of girlhood. Nevertheless, one does wonder why Williams passes over so many girl characters in Shakespeare. One especially notable peculiarity is the absence of Margaret Plantagenet from Richard III, a character who has the distinction of being the only prepubescent girl in the Shakespeare canon who speaks. Miranda, Juliet, Ofelia/Ophelia, and others are girls as Williams rightly defines the term 'girl ... is not limited to chronology or biology' (6) — but it seems odd to omit the sole character who perhaps best fits the contemporary conception of 'girl'. Further, the choice to define Juliet, Miranda, Bianca, Silvia, and Ofelia/Ophelia as girls, in part because of their 'peevish' and 'perverse' behaviour, raises unanswered questions about the study's exclusions. Are characters such as Margaret, Desdemona, Cordelia, Lavinia, and Imogen not girls in these terms? If so, why?

Despite these limitations, Shakespeare and the Performance of Girlhood opens new doors for future studies of the legacy of Shakespeare and childhood. It is a text invested in Shakespeare studies, social histories, literary theory, and feminist studies that advances each of these fields. Williams's analyses and contextualizations of the works in question offer original ways of understanding the girls in Shakespeare's works and how such works went on to influence the modern understanding of girls and girlhood. 